\title{
Media Framing of US Drone Policy in the National Press of Pakistan
}

\author{
Dr. Akber Ali \\ Head of Department of Media \& Communication Studies \\ Karakoram International University \\ Gilgit-Pakistan \\ akber.ali@kiu.edu.pk \\ Rashid Hussain \\ Lecturer \\ Department of Media \& Communication Studies \\ Karakoram International University \\ Gilgit-Pakistan \\ rashid.hussain@kiu.edu.pk \\ Faiza Muneeb \\ Lecturer \\ Department of Media \& Communication Studies \\ Karakoram International University \\ Gilgit - Pakistan \\ faiza.munib@kiu.edu.pk
}

\begin{abstract}
United States drone policy has been fiercely debated both in the mediated and popular discourse in Pakistan. Despite the prevalence of the academic literature on drones, little is known hitherto how the elite- oriented press framed the US drone attacks in Pakistan. To that end this study informed by the framing paradigm, qualitatively analyzed the editorial genres of national press of Pakistan. The analysis identified four major frames or 'interpretive packages' the press used to construct the discourse on US drones namely sovereignty violation frame, collateral damage frame, connivance frame, and blowback frame. The findings suggest that drone strikes in Pakistan are represented unfavorably with an overall negative tone toward the drone strikes and the United States and its policies in the region. The discussion elaborates on the possible factors which contributed for the emergence of new frames in the context of Pakistani media.
\end{abstract}

Keywords: US drones, Pakistan press, news framing, inductive framing, qualitative analysis, Pakistan, US. 


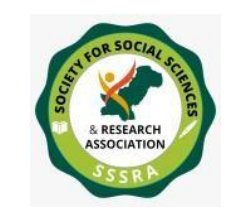

Pak. Journal of Int'L Affairs, Vol 4, Issue 3 (2021)

Media Framing of US Drone Policy ...

\section{Introduction}

In the post 9/11, the United States has launched Unmanned Aerial Vehicles (UAVs) or so called drones as centerpiece of counterterrorism policy in certain regions of Asia and Africa including Pakistan eliciting much contested debates among the legal community, UN officials, political and independent actors and the targeted countries vis- à-vis the legality, morality and effectiveness of usages of drones as counterterrorism policy. While the United States has had defend the drone strikes as legal and effective way against terrorism as the former president Obama put it 'just war' of self defense against militants and posited that the drone usage had made the US secure (BBC 2013), the drone program of the US is reported to be highly unpopular both globally and within the targeted countries (Pew Research Centre 2013). Pakistan is one of those countries which were highly targeted by the US drones since 2004 which had increased to six times higher during the Obama Administration compared to the Bush administration (Boyle 2013). Two contrasting narratives exist in Pakistan over the US drones. On the one hand majority of the surveyed public overwhelmingly opposed the drones (Pew Research Centre 2012). On the other hand, studies have argued that drones are appreciated as effective tool against the militants by the people in the FATA ${ }^{1}$ region of the country wherein the drones are operative and that the claims of the collateral damage are not truthful ( see Shah 2016; Taj 2010; Williams 2010 ). Pakistani officials have had shown their concerns about the drones. The former Pakistan Army Chief, General Raheel Sharif had termed the drones as regrettable as they are a "threat to the sovereignty and security of the country" (Haider 2016). In a similar vein, the former president Asif Zardari during his meeting to David H. Petraue-the then head of the US Central Command complained about the drone strikes in Pakistan and said,

"continuing drone attacks on our territory, which result in loss of precious lives and property, are counterproductive and difficult to explain by a democratically elected government. It is creating a credibility gap" (New York Times 2008).

With this background in view, the current study is aimed to delve into how the news media of Pakistan framed the US drone issue and how it could be contrasted to similar media studies in the Western media and what could be possible explanations for the similar or differing media narratives across the political and cultural settings. News media have emerged as important social and political institutions in Pakistan during the last few years in shaping and molding the public discourse on important national and international issues. Thus studying the news discourse on drones is timely as the public legitimacy or lack of it about drone strikes can have serious implications for Pakistan, the US and the global war on terror. With this background in mind, we qualitatively analyzed

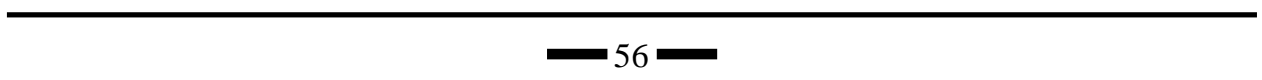




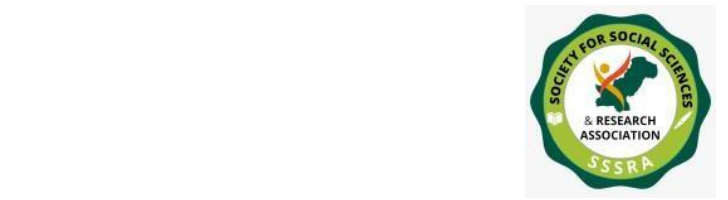

the news framing on US drones in the elite press of Pakistan. The significance of the study lies in the fact that comparing media narratives across the political and cultural setting could provide insights about the media in their interpretations of issues of national and global scope. Moreover, the existing studies on media narratives on the controversial US drone policed are skewed in the sense that they provide the Western media narratives supporting this controversy policy. It is yet to be explored how the news media in the targeted countries like Pakistan interpret the US drone policy. To that end, the current study provides a national and indigenous media perspective on US drones taking the Pakistani press as a case point.

\section{Literature Review}

In their cross national media framing on US drones, Sheets, Rowling and Jones (2015) have found contrasting frames with the US media predominantly framing the drone policy to be legal, strategically valuable, and technologically sophisticated while downplaying the collateral damage the droned caused. The press in the Britain and the Arab world on the other hand were more critical about the drones and the collateral damage as a result of the drone strikes. Ottosen (2014) in a comparative analysis of the legal aspects of the drone strikes in the New York Times and the Norwegian newspaper Aftenposten have concluded the both the newspapers were uncritical in their coverage vis-à-vis the legal aspects of drone strikes. Bachman (2015) has revealed that the New York Times and Washington Post misled the public about the US drones in their news coverage and concluded that both the elite newspapers failed to report the civilian casualties accurately and instead echoed the US officials' narratives on drone strikes uncritically. Storie, Madden and Liu (2014) have found that the US media framed the killing as a great breakthrough in the war on terror and a great victory for the US; the Russian media on the other hand frame the killing in ambivalent terms and used the secrecy and humanizing frames showing much cynicism toward the US action. What remains to be explored how the news media of the targeted countries framed the US drones. Pakistan offers the best case to be examined for the media narratives on the US drone policy.

\section{Theoretical Framework}

A key theoretical framework that helps us to understand how the news media make sense and constructs social reality is the framing theory. Framing refers to the typical manner in which journalists shape news content within a familiar frame of reference (van Gorp 2007) or "organizing principles that are socially shared and persistent overtime, that work symbolically to meaningfully structure the social world"

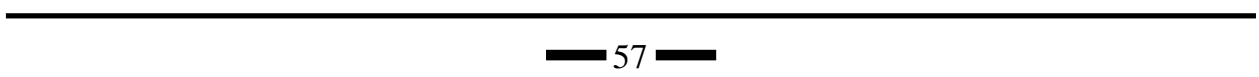




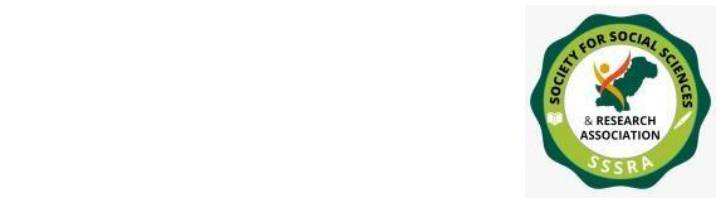

Media Framing of US Drone Policy ...

(Reese \& Lewis 2009). Frames are also noted to be "interpretive packages" (Gamson \& Modigliani 1987) or a stimulus to read a news story in a particular direction to promote a specific definition of an issue (van Gorp 2007). A widely cited concept about framing has been given by Entman (1993) which states:

To frame is to select some aspects of a perceived reality and make them more salient in a communicating text, in such a way as to promote a particular problem definition, causal interpretation, moral evaluation, and/or treatment recommendation for the item described. (Italics in original, p.52)

Gitlin (1980 p.7) writes "media frames, largely unspoken and unacknowledged, organize the world both for journalists who report it and, in some important degree, for us who us who rely on their reports". Serving as organizing schemes, frames provide coherence to the writers with which some critical issues can be discussed (see Lee 2002). Framing tells the power of the media discourse in constructing social reality by highlighting, repeating, and reinforcing certain aspects while excluding others in order to evoke audience attention to some aspects and making them seem natural and common sense. Scholars have also noted that new media frames can be 'episodic' or 'thematic' (Iyengar 1991). Episodic frames refer to a specific event or issue and therefore are event or issue-specific. Thematic frames in contrast are more analytical, broader, and contextual providing a more detailed background or historical context to issues or events under discussion. Thus the drone strikes can be framed as a single policy issue or in broader context of the war on terror.

\section{Methodology}

This study utilizes the inductive framing approach to explore the news media content qualitatively to distill the recurring themes and patterns that will constitute frames or 'interpretive packages'. Inductive framing is noted to be useful for a phenomenon which has not been explored previously and involves analyzing a news story with an open view to "attempt to reveal the array of possible frames, beginning with very loosely defined preconceptions of these frames" (Semetko \& Valkenbburg 2000, p. 94; see also Golan \& Lukito 2015). This approach is suited to explore a topic in more details going beyond the text and provide implicit patterns and themes which mere counting the frequencies of the words may not reveal. We argue that in the context of Pakistan, no priori studies have been conducted on drone and media narratives, thus we are reluctant to use a priori defined frames as have been employed in the previous studies (see Sheets, Rowling \& Jones 2015; Jones, Sheets \& Rowling 2013), instead an inductive framing coupled with the qualitative approach is more astute in our case. 


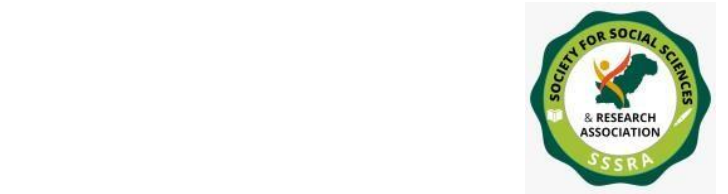

Two elite major English dailies The News and The Nation were selected. The News is the largest English newspaper in Pakistan with a high circulation and widespread readership belonging to the largest media group (Onyebadi 2016). The Nation is also considered a major elite newspaper of Pakistan (Romero-Trillo 2011; Archetti 2010) with a conservative orientation. All editorials that appeared in the two dailies dealing with the US drones specifically were selected from the online archives from 2010 to 2016 (both years inclusive) and were analyzed qualitatively for the dominant narratives on the drone policy. The time period is pertinent because during the Obama administration the drones strikes had substantially increased compared to the previous US administration (Bergen \& Tiedemann 2010). The unit of analysis was the individual editorial. The rationale for selecting the editorial lies in the fact that editorials are important news genres that reflect the ideological stance of the news media organizations (Izadi \& Saghaye-Biria 2007) and offer an important site to study the ideological positions of news on major issues (Lee et al. 2011; Le 2006).

\section{Findings and Analysis}

An inductive thematic analysis propounded by (Braun \& Clarke 2006) was followed to compare between each editorial to distill the dominant frames. By using the constant comparison method (Strauss \& Cobin 1990) the themes expressing same ideas and having similar linguistic chrematistics were merged into a single. For instance the violation of sovereignty and the violation of international law were merged to form the 'sovereignty violation frame' as both themes express similar ideas. Finally special attention was given to the framing and reasoning devices e.g. choices of words, metaphors, catchphrases, use of sources, moral evaluation, narratives and repeated uses of phrases each editorial used to build the frame package. Overall four major frames on US drones strikes namely:

sovereignty violation frame, collateral damage frame, blowback frame and connivance frame.

These frames were not mutually exclusive rather appeared simultaneously in the editorial discourse on drones as dominant frames

\section{Sovereignty violation frame}

A dominant frame that frequently employed by the news media in Pakistan was the "sovereignty violation frame". The article within this frame implicate the US drones are illegal and a violation of sovereignty of Pakistan. To build this frame package, the

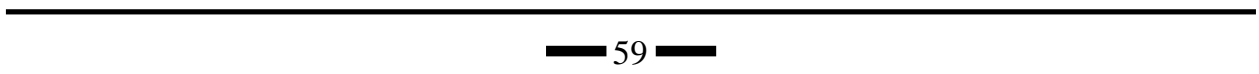




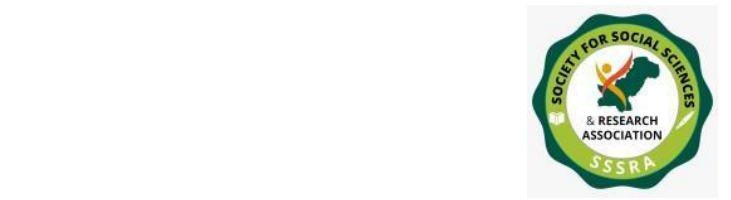

newspapers in their editorial discourse frequently referred to the International Law and Human Rights charter of the United Nations that obligates the states to respect the sovereignty of other states. This frame is used predominantly in each editorial discourse implicitly or explicitly. The US is portrayed as an intruder of a sovereign nation and 'wanton violator of human rights' (The News, July 3, 2016) because the drone attacks occur in areas which are not active war zones and without the consent of Pakistan thus deemed illegal. The drones are often referred to kill innocent men, woman and children. Even when there were confirm reports of killings of the high value targets, the press repeatedly trumpeted the sovereignty violation. The US is frequently depicted as disrespectful to Pakistan and its citizenry and unaccountable to its illegal actions like drones. As seen in the following excerpt:

The US still retains the right to militarily attack Pakistan with UAVs [Unmanned Aerial Vehicles] in a blatant violation of international law. (The News, August 2, 2014)

The US, as the unadvised drone attacks on our tribal areas have shown, seems not to bother about Pakistanis sensitivities on the question of territorial sovereignty, at least as far as the tribal areas are concerned. (The Nation, July 8, 2010)

US drones' strikes are frequently termed as 'drone wars', 'war practices', 'killer drones' 'American impunity', 'American imperialism', 'lethal drones', 'our integrity 'and a ' human rights landmine' (The Nation, July 4, 2016) and 'regular invasion of Pakistan's sovereignty' (The News, July 4, 2013). Often the public feelings and sentiments were mentioned to build a narrative that the whole nation is against the' invasion' by US drones. As one such piece of editorials narrates:

Each drone attack hits the Pakistanis' sense of independence hard, with the country's borders, for all intents and purposes, lying the totally open to invasion by drones. (The News, May 31, 2012).

The overall tone in the editorial discourse toward the US remained highly negative and unfavorable and the American actions were often mentioned as controversial, unilateral and imperialistic in their designs as seen in the following excerpt.

American impunity for its controversial war practices remains total. What is happening in Pakistan is only a microcosm of the global injustices enacted by the US military

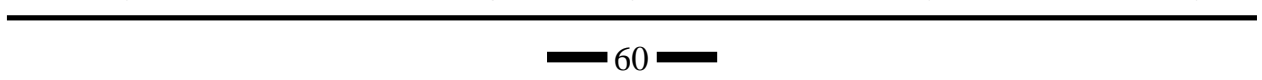




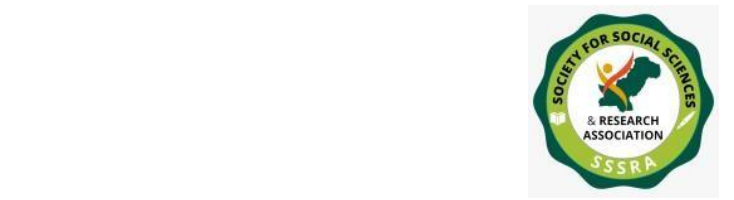

apparatus. The global balances of forces can only be tilted if the sovereign governments get together to challenge US war practices. (The News, June, 2, 2016).

Interestingly, as framing and reasoning devices, the newspapers often used the independent sources including the UN agencies, EU to build the narrative of the sovereignty violation. Frequently the discourse mentioned the US thinkers and the public as 'conscientious' who also condemn the US drones as a sovereignty violation and against the international law. The newspapers frequently reported while discussing the drone strikes that the whole international community is against the US drones and considers it as violation of international law except the US. It repeatedly recommended Pakistan to take the issue to the international forums for being 'bombed by the US without war being declared in the area (The News, July, 29, 2013).As seen in the following editorial pieces:

EU parliament expressed its deep alarm over the moral, ethical and human rights implications of what it called the "US targeted killing programme". (The Nation, March $17,2013)$

Even American thinkers and analysts are beginning to regard the drone attacks as against the international law. The UN human rights body has clearly and unambiguously pronounced against it [drones]. (The News, June 10, 2013).

The editorials also echoed the UN to stop the US drones and to make sure the US follows the international law as failing to it will encourage other state to achieve the drone technology and will use it unbridled. In a number of editorials, the UN was repeatedly asked for the regulation of drones to avoid its misuse.

The UN'S duty is to develop these rules even when the US is the only country to possess and use armed drones.....Far better to bring the armed drones under the rubric of international law no rather than wait for this eventuality. (The News, December, 21, 2013).

Surprisingly, the newspapers failed to mention whether the militants and their hideouts in the tribal areas of Pakistan who do not accept the Pakistani law is also a violation of sovereignty or not and how they be treated? Interesting, despite the fact that Pakistan is a US ally on war on terror, the dominant narratives echoed in the elite English press of Pakistan framed the drones as violation of 'our sovereignty' thus deemed illegal and

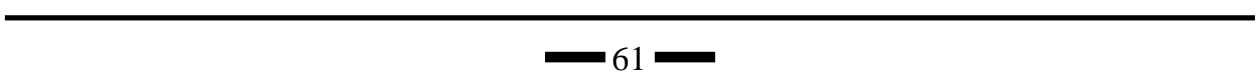




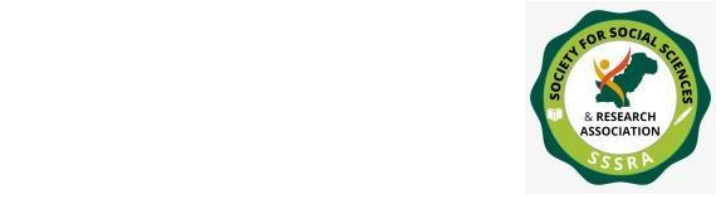

illegitimate no matter that these very drones have killed some of the most wanted terrorists who were involved in the terror acts in Pakistan and Afghanistan. Thus by including certain aspects of a reality and excluding others (Entman 1993), the newspapers discursively framed the US drones strikes as violation of Pakistan's national sovereignty. The newspapers frequently narrated the 'US war on terror' signaling that the war on terror is not our war rather 'their' war. In one such discourse, The Nation criticized the US policies and anticipated that, "without the USA rectifying its policies, there is no hope for its making of the world safe for American citizens, the supposed goal of its war on terror" (The Nation, March 26, 2011).

\section{Collateral damage frame}

A prominent and recurring frame that emerged in the editorial discourse is the collateral damage that the drones are killing civilian's including men, woman, children and the people of tribal areas who happened to be there during the strikes. Almost all editorials mentioned in one way or the other the civilian killings, the suffering of the local people and the psychological ills the drones are bringing to the local population. Even, when a known terrorist is killed by the drones, the newspapers were reluctant to accept is a breakthrough rather mentioned the civilian causalities. Frequently the drones attacks were mentioned as 'killed people' even if there was statement both by the US and Pakistani officials for killing a high value-target. By repeatedly mentioning the civilian deaths (which was not confirmed by any source) the frame referred to the maximum number of innocent killings and trivialized the effectiveness of the drone strikes against the militants. For instance when Baitullah Mehsud- the then Taliban leader was killed in drone attack, the newspapers termed it a killing of a few at the cost of hundreds. Public gatherings, marriage ceremonies and other civilian activities were echoed to construct the reality that the drones are killing 'innocent people'. The phrase of 'killing people' was predominantly used to build the narrative that drones kill people which connote the killing of civilians. Human interest stories were often mentioned to give a humanitarian sense to those being killed by the drone strikes. Frequently the discourse of civilian killing was juxtaposed to the sovereignty violation as has been narrated in the following excerpts:

The US killing spree in our tribal areas continues, as four more people were killed and many more injured in a drone attack on a residential compound in North Waziristan on Friday. So far over 1,000 people have died in these attacks (The Nation, April 18, 2010)

Drones strikes have continued since the change of the government and none of the government and none of the main stream political parties and their stances appear to have

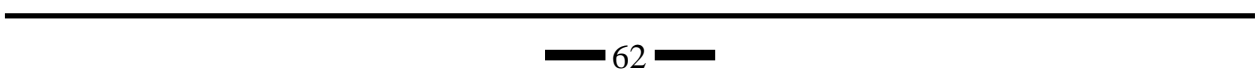




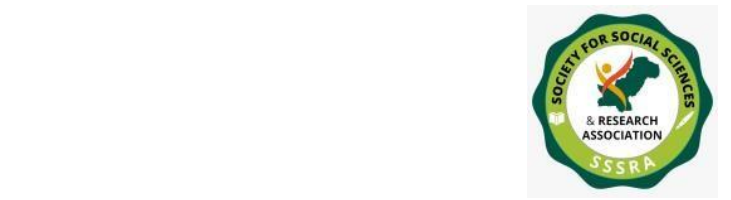

Pak. Journal of Int'L Affairs, Vol 4, Issue 3 (2021)

Media Framing of US Drone Policy ...

had much impact when it comes to deterring the US from its regular invasion of Pakistan's sovereignty and the killing of its citizens. (The News, July 04, 2013).

The Nation remained critical about the US drones and depicted a highly negative image of the US and its actions as 'brutal' and 'uncivilized'. In a hard hitting editorial on the Obama's speech on the need to better ties with the Muslim world, The Nation in one such editorial piece termed it as eyewash as the US is engaged in the butchering of people. As the excerpt narrates:

At a time when the war is killing and maiming people in Afghanistan and Iraq and US drones are butchering the tribal population in FATA, his words of support and the plan to improve relations is merely eyewash. (The Nation, April 29, 2010)

The very notion that the life of an average American can be made more safe and secure by killing some militants and at the cost of the civilian lives virtually blurs the difference between the civilized people and the barbarians. (The News, May 17, 2013).

In a number of editorials the efficacy of the US drone technology in hitting only the 'militants' was challenged as the area where the drones are fired is inaccessible to the media and independent sources and is ' guided by the poor intelligence that results in the death of innocents' ( The Nation, April 25, 2015). Criticizing the overall US drone policy one editorial commented about it as the 'broad policy does not attribute much value to innocence of victims, principle of justice and morality' (The Nation, April 25, 2015).

Using the sources as framing techniques, the newspapers often mentioned the reports of the independent organization on civilian killings that refute the US claims of the minimum collateral damage. As the excerpt illustrates:

The opposition to drones by the human rights groups and even the some of the US allies stems from the fact that the manner in which these killer flying machines are being employed is also causing a large number of deaths of civilians who are by and large innocent. (The Nation, February, 4, 2013)

On many occasions the newspapers rejected the US reports of killings of the militants by drones stating that the "precise truth as to who was killed and where is of course impossible to establish. (The News, August 27, 2012). The technological precision and the poor US intelligence in identifying the drones appeared as a frequent comment implicating that the drone technology is not effective and precise. A sub-theme of collateral damage was the US disregard for Pakistani lives. A typical example is:

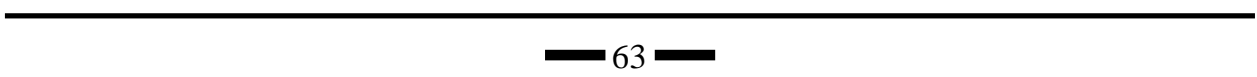




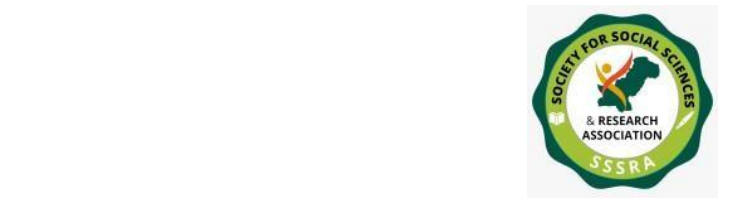

Media Framing of US Drone Policy ...

In fact, the US continues to convert Pakistan effectively into a satellite state. It continues to target Pakistani citizens in FATA through drone attacks and its personnel ride roughshod all across Pakistan with a total disregard for its laws and people, including their lives. (The Nation, July 17, 2010)

Often the US reports on killing of high value targets were rejected by bringing into the collateral damage the drones have brought to Pakistan. Collateral damage- the killing of innocent people in the US drones was a recurring theme appeared in the editorial discourse even in the editorials which sometimes mentioned the killings of high value profile militants but the press downplayed the most wanted killings by frequently highlighting the killings of common in the drone strikes. Although less often the killing of the militants in the US drones was mentioned, but trivialized by stating 'the civilian price is far too much to justify the death of occasional militant criminals' (The News, May 10, 2013). Moreover, more threatening and emotive terms were used often to refer to the US drones ranging from' killing drones' , ' killer robots in the sky' , 'lethal drones', ' ugly drones', ' deathly drones', ' aerial massacre', 'saga of killing' and ' killer flying machines', ' US mercenary forces' to mention a few. Using these framing and reasoning devices the drones were frames highly negatively that kill 'people'. Interestingly, the discourse on the drones is not limited to drone strikes but also paints a highly negative image of the US as "rough elephant that causes great damage wherever it goes" ( The Nation, December, 29, 2010).

\section{Connivance frame}

When the United States did not stop the drones and the Pakistani government failed to 'shoot the drones' as desired by the press despite the capacity of the Pakistani forces; the press echoed that both the military and civilian officials of Pakistan are secretly supporting the US drone program contrary to their opposition to drones in their public posturing. A substantial number of editorials reported the alleged complicity of the Pakistani government in supporting the US drone program. Both the newspapers were critical toward the Pakistani state for not telling the truth regarding the tacit agreements with the US over the much 'hated strategy' of the drone strikes. For example in one such editorial comments with the headline of "Our leaders' deceit" (The Nation, September 17, 2010) the Pakistani officials were criticized for their complicit vis-à-vis drone attacks in Pakistan and argued that the Pakistani leadership lacks moral courage to tell the truth about drones. As one editorial comment illustrates:

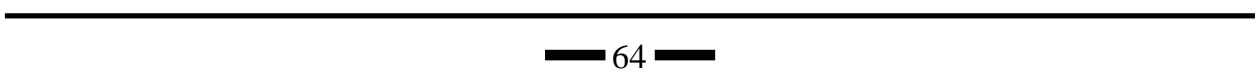




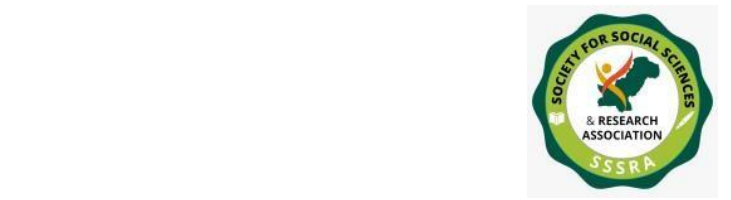

It has come as no surprise to hear Richard Holbrooke state, simply and clearly, that the US drone attacks are being carried out with the approval and close collaboration of the Pakistan civil and military leadership. It is shameful how this leadership has continued to lie to its people on this critical issue. (The Nation, September 17, 2010).

In a number of editorial comments both the newspapers remained critical for the powerlessness and callous attitude of Pakistani officials in their failing to stop the US drones. As the excerpts illustrate:

...the ritual of crying over violated sovereignty and innocent deaths is all we going to get....the US has sometimes found a willing partner in Pakistan for its drone attacks. (The News, June, 2, 2016).

A recurring theme in the editorial was the support for the civilian government to take charge of the security matters and to a course that is in the interest of the country. When the former Pakistani military officials conceded before a commission that there is an understanding with the US on drones, The Nation termed it as 'startling and seemingly out of character admission.' (The Nation, July 11, 2013). In a comment the same newspaper noted that the 'aerial massacres that the USA keeps committing should not longer have an impunity granted by the government connivance (The Nation, June 7, 2011). Many editorials suggested shooting the drones, ending the NATO supply lines and leaving the war on terror if the US does not stop the drones. But when the government did none of these actions, the newspapers reported as an evidence of the complicity of Pakistani rulers vis-à-vis drone. As one such comment reads, '...the biggest evidence of the government complicity in drone strikes is that it has yet to use the leverage at its disposal that range from the halting NATO supply to ....using its own air to down these robotic machines ( The Nation, April 20, 2011). A related sub-frame of the connivance frame was the lack of transparency on the part of the Pakistani official pertinent to the US drone strikes that was often mentioned in the news editorial discourse. As one such editorial reads:

The fact that there is no transparency in the agreements that exist between Islamabad and Washington in various spheres only adds to the feelings of disquiet amongst people (The News, August 27, 2012).

Secret agreements made outside the public realm add to the complications. It is hardly democratic to lie and fool people. (The News, May 18, 2011).

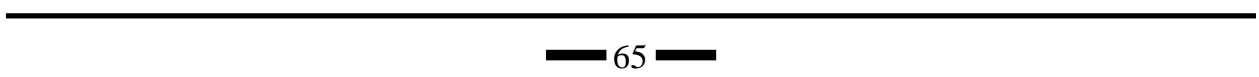




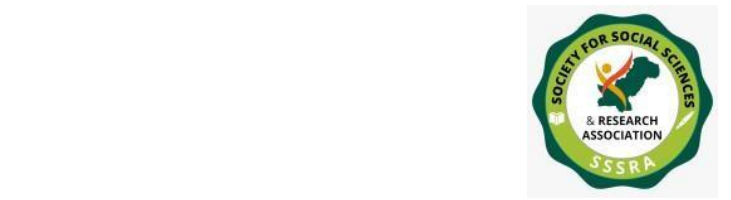

Notably, a number of editorials termed the existing Pak- US relations as murky and a one sided embracement that must be revisited and made transparent before the public as there is little doubt that there are ' invisible agreements behind the scenes' (The News, May 25, 2013). It should be noted that the media equally remained critical towards Pakistan's policies vis-à-vis the militants in addition to the critical stance towards the US. The press echoed on few occasions that Pakistan's wrong policies of past and unclear policies of present pertinent to the US have brought the issues of extremism and terrorism in Pakistan. The frame of connivance echoes repeatedly that the Pakistani officials are tacitly supporting the US drones despite their opposition to drones in their public posturing.

\section{Blowback frame}

The news media often utilized "blowback frame" as central organizing idea that the US drones policy is not only ineffective but also counterproductive for a number of reasons ranging from fueling extremism and terrorism to anti-Americanism and instability of Pakistan. Arguments were consistently advanced in the editorials to build a narrative that the drones do not help to end terrorism rather they cause more terrorism in Pakistan and create further resentment against the US and its policies. The sub-themes of blow effect theme were the anti- Americanism and more terrorism as a result of the US drone strikes. Both The Nation and The News consistently constructed a narrative that the US drones are the primary cause of the terrorism in Pakistan as those who are being killed by the drones take revenge from the Pakistani state given their inability to attack the US and its citizens. As the excerpt shows:

The deadly suicide hit ripping apart an IDP camp in Kohat killing a large number of people including women and children, coupled with the spate of mass casualty blasts during the past few days that have rocked Quetta and Peshawar, is a grim reminder of how seriously the fallout from the drone attacks is destabilizing the country. (The Nation, April 18, 2010).

The Nation consistently attributed the responsibility of terrorism and suicide bombing in Pakistan to the US drone attacks and reported that the drones are destabilizing Pakistan. It frequently echoed that the fallout of the drones serves the interests of the terrorists who can easily recruit militants to take vengeance. As the following excerpts illustrate:

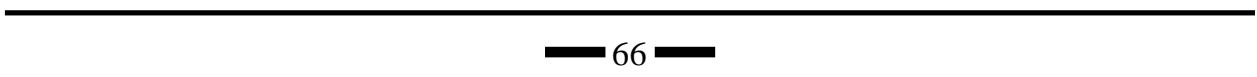




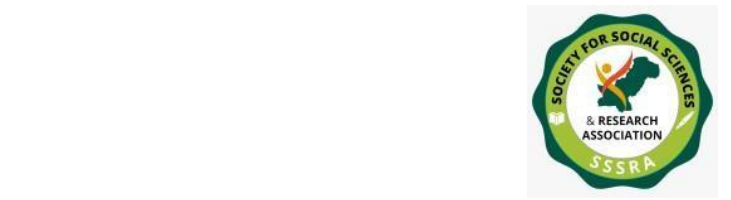

Pak. Journal of Int'L Affairs, Vol 4, Issue 3 (2021)

Media Framing of US Drone Policy ...

For Pakistan the US drones have been a major factor in the increase in extremism, the spread of violence and terrorism and socio-political instability. (The Nation, May 20, 2010)

The News, on the other hand reported more on the resentment and anti-Americanism the drone caused in Pakistan. In a number of editorials the daily mentioned the growing public feelings and outrage against the Pakistan officials in their failure to stop the drones. It further noted these drones are a direct cause of anti-Americanism in Pakistan. For example: The drone strikes play directly into the hands of the very extremists they are supposed be targeting, and are seen by a battered public as cruel aggression. (The News, April 25, 2011).

Public attitude are now so deeply anti-American that it could take a generation to roll back the negativity- or perhaps this now be Pakistan's default position (The News, June, 07, 2012).

In a number of editorial comments the newspapers frequently argued that the US cannot win the war on terror until the drones are stopped as the fallout of drones creates a generation of terrorists in the Pakistani society. Drones were highly criticized for their inefficacy as well. Many editorials headlines read, 'drones don't help,' 'drones and dilemmas', 'massacre by drones' in an attempt to advance an argument that the drones are not serving the purpose of ending extremism and terrorism, rather these very drones are destabilizing Pakistan. For example:

For the Americans to continue the use drones as they are currently, they are doing no more than creating a giant storage battery of extremism that will fester for a generation or more (The News, April 25, 2011)

And the death of civilians leads to the recruitment of their kith and kin in the ranks of terrorists groups; so, far killing one militant, the price in the form of a swelling the ranks of militants is nothing but counterproductive, fanning the fires of vengeance and retribution. In sum total, the US and its allies are the clear losers (The Nation, May 10, 2013).

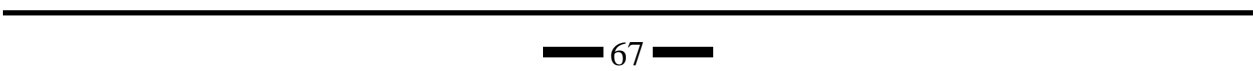




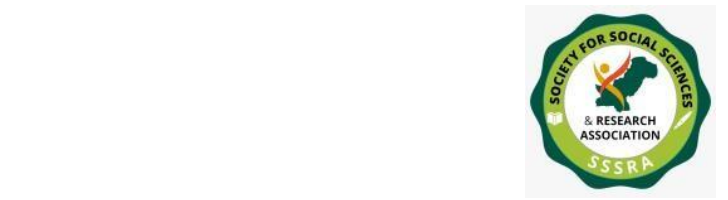

Pak. Journal of Int'L Affairs, Vol 4, Issue 3 (2021)

Media Framing of US Drone Policy ...

The sufferings of the local people owing to the drone attacks and the victims were also made part of the discourse to build a narrative that those whose nears and dears were killed by the drones had no other option than to take revenge by killing the masses by suicide attacks. Even the US aid and its failure to deliver was linked to drone policy in an tempt to evoke the repercussions of US drone strikes in Pakistan. As narrated below:

While the US attempts to win friends through its assistance with flood relief, the continued drone attacks in the tribal areas achieve the opposite. ..each such strike builds distrust for the US. ....the best strategy for this needs to be thought out and perhaps more thinking put in as to whether bombs and gifts basket can go genuinely together (The News, September 14, 2010).

Frequently the protests against the drones were narrated to build an argument that the common people of Pakistan are against the drones and that the rage is natural 'that would run through the heart of any father when he sees his child torn to pieces by US plane' (The News, May 31, 2012). Additionally, the drones were frequently mentioned as an irritant to improve an already fractured relationship between Pakistan and the US.

\section{Discussion and Conclusion}

In the extant scholarship on US drones as a security policy, less attention has been paid to the news framing of the policy in the targeted countries like Pakistan. This study attempted to build on the existing media scholarship on the US drone policy by inductively examining the media narratives in the national press of Pakistan. The discursive examination of the editorials in the two major English dailies identified four dominant frames or "interpretive packages" (Gamson \& Modigliani 1989) namely the sovereignty violation frame, the connivance fame, collateral damage frame and the blowback frame. These frames are various conceptualizations and interpretations within which the news media in Pakistan construct the discourse on a contested and controversial security policy launched by the US. What these findings reveal on a controversial US security policy? First, in contrast to the existing scholarship on US drones (see Sheets et al., 2015) this study argues that the existing frames and media narratives on the US drones are West-specific mainly drawn from the Western media narratives thus do not provide the perspective on drones from the news media of the targeted countries such as Pakistan. In this sense the present study adds to the existing media scholarship on drones by revealing two additional media frames or perspectives namely the connivance frame and the blowback frame. The connivance frame echoes that there exists a tacit support of the Pakistani officials to the US drones despite their 


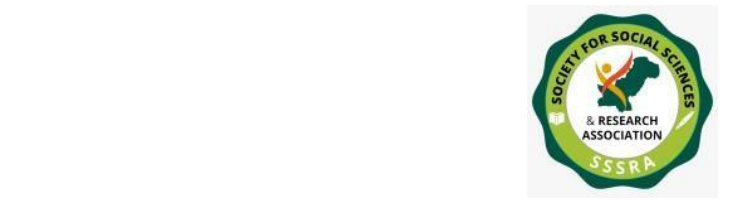

opposition to drone strikes in the public posturing. The blowback frame argues that the drone attacks create more terrorists and fuel extremism in Pakistan thus deemed as counterproductive. Comparing these new findings with the existing US media narratives on US drones - which by and large framed the US policy as effective, legal and in uncritical standpoint ( Sheets Rowling \& Jones, 2015), it could be concluded that the media narratives on issues of global scope like the drone policy are country and cultural- specific. Thus media in both social and political systems frames the drones according the social and political realities of their respective countries instead of taking a non-partisan standpoint. Further, the dominant frames and accounts employed by the press in Pakistan and its comparison to the US media narratives; it is suggestive that the professional, cultural and arguably the national identity are explanatory factors that shape the media narratives on international events. Although it is beyond the scope of the current study to show definitively that the aforementioned factors shape the media narratives on US drones policy, nonetheless, on the basis of the prior literature it can be said that these cultural and national contexts do have important implications on how news of global scope are framed in national media discourses (see Entman 2004; Rivenburgh 2000). In sum, this study shows that the existing media scholarship on US drones is one-sided thus do not provide the larger global picture beyond the Western media narratives. It thus adds to the existing media literature on US drones by finding additional narratives from the targeted countries perspectives. Future studies could examine how the drone policy is narrated in other targeted countries of Africa and Asia to provide a holistic media narrative on a controversial US security policy across the political and cultural settings.

\section{Notes}

1. FATA (Federally Administered Tribal Areas) is the restive region of Pakistan bordering Afghanistan where the US drones are operating. 


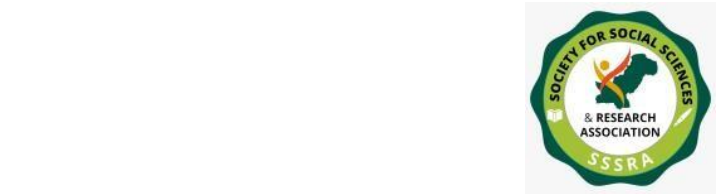

Pak. Journal of Int'L Affairs, Vol 4, Issue 3 (2021)

Media Framing of US Drone Policy ...

\section{References}

Archetti, C. (2010). Comparing international coverage of 9/11: Towards an interdisciplinary explanation of the construction of news. Journalism, 11 (5), 567588

Bachman, J. (2015). The New York Times and Washington Post: Misleading the public about US drone strikes. Journalism Studies, 1-25.DOI: http://dx.doi.org/10.1080/1461670X.2015.1073118

BBC ( 2013). Barak Obama defends 'just war' using drones. Retrieved from: http://www.bbc.com/news/world-us-canada-22638533, Accessed on, August 10, 2017.

Bergen, P. \& Tiedemann, K. (2010). The year of the drone. New York: New American Foundation.

Boyle, M.J. (2013). The cost and consequences of drone warfare. International Affairs, 89 (1), 1-29.

Braun, V., \& Clarke, V. (2006). Using thematic analysis in psychology. Qualitative Research in Psychology, 3 (2), 77-101.

Entman, R.M. (1993). Framing: Toward clarification of a fractured paradigm. Journal of Communication, 43 (4), 51-58.

Entman, R.M. (2004). Projections of Power: Framing News, Public Opinion, and US foreign Policy. Chicago: University of Chicago Press.

Gamson, W. A. \& Modigliani, A. (1989). Media discourse on nuclear power: a constructionist approach. The American Journal of Sociology, 95(1), 1-37.

Gamson, W.A. (1988). A constructionist approach to mass media and public opinion. Symbolic Interaction, 11 (2), 161-174.

Gitlin, T. (1980). The whole world is watching. Berkeley: University of California Press.

Goaln, G.J., \& Lukito, J. (2015). The rise of the dragon? Framing China's global leadership in elite American newspapers. The International Communication Gazette, 0 (0), 119.

Haider, M. (June 1, 2016). US drone strikes regrettable, must stop: COAS. Available at: http://www.dawn.com/news/1262054, Retriewed on n Feb 5, 2017.

Iyengar, S. (1991). Is anyone responsible? How Television frames political issues. Chicago: University of Chicago Press.

Izadi, F., \& Saghaye- Biria, .H. (2007). A discourse analysis of elite American newspapers editorials: the case of Iran's nuclear program. Journal of Communication Inquiry, 31 (2), 140-165.

Jones, Timothy and Sheets, Penelope and Rowling, Charles, Differential News Framing of Unmanned Aerial Drones: Efficient and Effective or Illegal and Inhumane? 
(2011). APSA 2011 Annual Meeting Paper. Available at SSRN: https://ssrn.com/abstract=1900579

Le, E. ( 2006). Collective memories and representation of national identities in editorials. Journalism Studies, 7 (5), 708-728.

Lee, C.C. (2002). Established pluralism: US elite media discourse about China policy. Journalism,

New York Times. ( Nov 3, 2008). Petraues in Pakistan Hears Complaints About Missile Strikes.

Available

at: http://www.nytimes.com/2008/11/04/world/asia/04pstan.html.

Onyebadi, U. (2016). Framing from the inside: An examination of Pakistani newspapers' house editorials on Osama bin Laden's targeted assassination. The Journal of International Communication, 22 (1), 108-125.

Ottosen, R. (2014). Underreporting the legal aspects of drone strikes in international conflicts: A case study of how Aftenposten and The New York Times cover drone strike. Conflict \& Communication [online], 13 (2), 1-12.

Pew Research Centre (June 29, 2012). Little support in Pakistan for US drone strikes targeting extremist leaders. Available at: http://www.pewresearch.org/facttank/2012/06/29/little-support-in-pakistan-for-american-drone-strikes-targetingextremist-leaders/, Accessed on August 2, 2017.

Pew Research Centre (Oct 23, 2013). Report questions drone use, widely unpopular globally, but not in the U.S. Available at: http://www.pewresearch.org/facttank/2013/10/23/report-questions-drone-use-widely-unpopular-globally-but-notin-the-u-s/, Accessed on August 11, 2017.

Reese, S.D., \& Lewis, S.C. (2009). Framing the war on terror: the internalization of policy in the US pres. Journalism, 10 (6), 777-797.

Rivenburgh, N.K. (2000). Social identity theory and new portrayals of citizens involved in

international affairs. Media Psychology, 2 (4), 303-329.

Romero-Trillo, J. (2011). The representation of liminality conflicts in the media. Journal of Multicultural Discourse, 6 (2), 143-158.

Semetko, A.H.,\& Valkenburg, P.M. (June 2000). Framing European Politics: A content analysis of press and Television news. Journal of Communication, 50 (2), 93-109.

Shah, A. (May 22, 2016). Why drone blowback in Pakistan is a myth. Dawn, Available at: $\quad$ http://www.dawn.com/news/1259933, On Feb, 11, 2017.

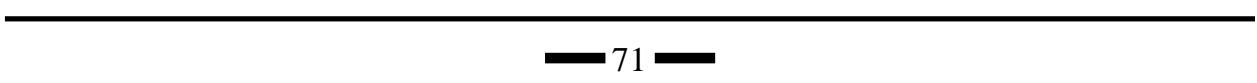


Sheets, P., Rowling, C., \& Jones, T.M. (2015). The view from above (and below): A comparison of American, British, and Arab news coverage of US drones. Media, War \& Conflict, 8 (3), 289-311.

Stories, L.K., Madden S.L., \& Liu, B.F. (2014). The death of bin laden: How Russian and US. Media frame counterterrorism. Public Relations Review, 40 (4), 429-439.

Strauss,A., \& Corbin, J. ( 1990). Basics of qualitative research: Grounded theory procedures and techniques. London: Sage.

Taj, F. (2010). The year of the drone misinformation. Small Wars \& Insurgencies, 21 (3), 529-535.

van Gorp, B. (2007). The constructionists approach to framing: Bringing culture back in. Journal of Communication, 57 (1), 60-78.

Williams, B.G. (2010). The CIA's Covert Predator Drone War in Pakistan, 2004- 2010:

The History of an Assassination Campaign. Studies in Conflict \& Terrorism, 33 (10), 871-892. 